\title{
Effects of culture conditions on acetic acid production by bacteria isolated from Ivoirian fermenting cocoa (Theobroma cacao L.) beans
}

\author{
Souleymane SOUMAHORO, *Bernadette G. GOUALIE, Jacques N. ADOM, Honoré G. OUATTARA, \\ Gisèle KOUA, Ginette G. DOUE, Sébastien L. NIAMKE \\ Laboratoire de Biotechnologies, Filière Biochimie-Microbiologie, Unité de Formation et de Recherche en Biosciences, \\ Université Félix Houphouët-Boigny, 22 BP 582. Abidjan, Côte d'Ivoire \\ * Corresponding author: bettygoualie@yahoo.fr
}

Original submitted in on $2^{\text {nd }}$ October 2015. Published online at www. m.elewa.org on 30th November 2015 http://dx.doi.org/10.4314/jab.v95i1.8

\begin{abstract}
Objectives: This study investigates the acidification capacity under various culture conditions of high acetic acid producer $A A B$ strains previously isolated from Ivoirian cocoa beans fermentation.

Methodology and Results: Effect of culture conditions was studied in agar medium and acid production was monitored by measuring the clear halo diameter during incubation. All tested strains showed acetic acid production at 30,35 and $40{ }^{\circ} \mathrm{C}$. Moreover, at initial concentration $0.1-0.4 \%$, lactic and citric acids stimulated acidification capacity of these strains with increase rate ranged from 50 to $100 \%$ while acetic acid reduced this capacity. In addition, maximum acetic acid production capacity was obtained for strains $123 \mathrm{D} ; 56 \mathrm{AB}$ and $49 \mathrm{D}$ at $8 \%$ ethanol initial concentration.

Conclusions and application of findings: This study shows that all tested strains are able to produce acetic acid under certain culture conditions similar to cocoa fermentation stress. However, cocoa fermentation assay is needed to better estimate the performance of selected strains.
\end{abstract}

Keywords: Acetic acid bacteria, acetic acid production, Cocoa fermentation, culture conditions

\section{INTRODUCTION}

Acetic acid bacteria (AAB) are Gram-negative bacteria with the ability to oxidize ethanol to acetic acid (Matsushita et al., 1994; Sievers and Swings, 2005; Sharafi et al., 2010; Kersters et al., 2006). In cocoa bean fermentation, the first step in chocolate production, $A A B$ play an important role for obtaining a well-fermented cocoa (Schwan and Wheals, 2004; Romero-Cortes et al., 2012). Generally, AAB emerged after $24 \mathrm{~h}$ of fermentation when air comes in fermentation heap (Nielsen et al., 2007) and then oxidize ethanol previously produced by yeasts to acetic acid by exothermic reaction. This acid diffuses into beans and in combination with heat produced by this exothermic bioconversion causes the death of the seed embryo as well as the end of fermentation. These biochemical changes are leading to the formation of precursor molecules that are necessary for the development of a characteristic aroma, flavour and colour of beans (Hansen et al., 1998; Thompson et al., 2001). These properties are further developed during drying, roasting, and final processing of 


\section{Soumahoro et al. J. Appl. Biosci. Effects of culture conditions on acetic acid production by bacteria}

isolated from Ivoirian fermenting cocoa (Theobroma cacao L.) beans

well-fermented cocoa beans (Thompson et al., 2001). Therefore, activities of $A A B$ during cocoa fermentation are essential for the production of high-quality cocoa (Quesnel, 1965). On the other hand, cocoa fermentation remains difficult to control leading to inconsistent production of cocoa quality. In this context, many studies suggest the use of microbial starter culture as a best approach to improve fermentation process (Passos et al., 1984; Hansen et al., 1998; Hashim et al., 1998; Nielsen et al., 2005; Papalexandratou et al., 2011). Therefore, several microbial cultures, including acetic acid bacteria have been assayed to assess their potential as starters and their effect on the

\section{MATERIAL AND METHODS}

Bacterial strains : Five (5) AAB strains including Gluconobacter oxydans strain (49D), A. pasteurianus (123 D), A. peroxydans (56 AB), A. aceti (139D) and $A$. pasterianus $(121 \mathrm{D})$ isolates recovered previously from Côte d'Ivoire cocoa fermentation were tested in this study. These strains were selected because of their high capacity to produce acetic acid in solid and liquid media (Soumahoro et al., 2015).

Analysis of acid production under various culture conditions

Effects of temperature and $\mathrm{pH}$ on acetic acid production: Effects of temperature and $\mathrm{pH}$ were evaluated in Hestrin-Schramm (HS) agar medium supplemented with green bromocresol and $4 \%$ ethanol as described by Andelib and Nuram (2009). The medium was spot inoculated with pure $24 \mathrm{~h}$ pre-culture of bacterial strain and incubated at different temperatures $\left(30,35,40,45\right.$ and $\left.50^{\circ} \mathrm{C}\right)$. To evaluate the effect of $\mathrm{pH}$ on acetic acid production, the HS medium was adjusted to different $\mathrm{pH}(4 ; 5 ; 6 ; 7$ and 8$)$. All cultures were incubated during 10 days at $30^{\circ} \mathrm{C}$ in

\section{RESULTS AND DISCUSSION}

Effect of temperature and $\mathrm{pH}$ on acetic acid production: The effect of temperature variation on acetic acid production capacity for $49 \mathrm{D}$ strain is available in figure 1a. The results showed a progressive increase of clear zone diameter during the first 7 days incubation at 30,35 and $40^{\circ} \mathrm{C}$. Then a stationary phase was observed until the end of incubation (Figure 1a). These results were same for all tested isolates. These findings are interesting because the cocoa fermentation is on average 6-7 days (Yao et al., 2014). quality of fermented product (Schwan, 1998; Lefeber et al., 2010; Lefeber et al., 2011; Papalexandratou et al., 2011). In this context, selected strains should be able to grow and produce metabolite essential for cocoa high quality under heap fermentation stress conditions mainly high temperature, variation of acids and ethanol concentrations. Previous studies have already evaluated the capacity of $A A B$ strains to grow under fermentations conditions (Soumahoro et al., 2015).The aim of this work was to analyse the capacity of these isolates to produce acetic acid under different fermentations stress conditions.

aerobic condition. The resulting diameter of yellow zone was measured daily. Acidifying capacity of strains was assessed by acid forming colony characterized by a clear halo with a diameter related to the amount of acid produced.

Effect of alcoholic and acid initial concentration on acetic acid production: Evaluation of acetic acid production capacity to ethanol, lactic acid, acetic acid and citric acid stress was carried out on HS agar medium as described by Andelid and Nuram (2009). Stress media were prepared using HS medium supplemented aseptically with alcohol and acids after sterilization. Their final concentrations (v/v) were ranging from 0 to 20 . The negative control with $4 \%$ alcohol did not contain the compound studied. The medium was spot inoculated as previously described and plates were incubated at $30^{\circ} \mathrm{C}$ for 10 days in aerobic conditions. The capacity of strains to produce acetic acid in alcoholic and acid stress conditions was assessed as previously described.

These findings suggest that the five tested strains in cocoa fermentation essay could continuously product acetic acid during the process. However, when the samples were incubated at $40^{\circ} \mathrm{C}$ a long lag time (2 days) was observed (Figure 1 a). Moryadee et al. (2008) reported an acetic acid bacteria strain isolated from fruit that produced acetic acid at $37^{\circ} \mathrm{C}$ with long lag time (3 days). Saeki et al. (1997) found also that the lag phase for ethanol oxidation was elevated (at $37^{\circ} \mathrm{C}$ ) and they suggested that the low productivity observed 


\section{Soumahoro et al. J. Appl. Biosci. Effects of culture conditions on acetic acid production by bacteria isolated from Ivoirian fermenting cocoa (Theobroma cacao L.) beans}

at this temperature might be attributed to the long time of adaptation of strains. In the context of cocoa fermentation, this adaptation time may promote reduction of acetic acid amount in cocoa beans fermenting heap and strongly influence the final cocoa quality. Indeed, Biehl et al. (1985) reported that high acetic acid amount is required for activation of the endoproteases activities and synthesis of amino acids, which are characteristics chocolate aromas precursors. Our results also showed that no acetic acid production was observed at temperature above $45{ }^{\circ} \mathrm{C}$. Yet, in previous studies, Soumahoro et al. (2015) demonstrated that all tested strains are able to growth at $45^{\circ} \mathrm{C}$ and strains $49 \mathrm{D}, 139 \mathrm{D}$ and $56 \mathrm{AB}$ at $50^{\circ} \mathrm{C}$. On the other hand, Saeki et al. (1997) demonstrated the increase in stability with increase of temperature (above $50{ }^{\circ} \mathrm{C}$ ) of enzymes notably alcohol dehydrogenase and aldehyde dehydrogenase implicated in conversion of ethanol into acetic acid (Tayama et al., 1989). Therefore, incapacity of these strains to produce acetic acid at $45^{\circ} \mathrm{C}$ is probably due to several factors unexplained in our knowledge especially since Moghadami et al. (2013) have demonstrated that thermotolerant strains have high ethanol oxidation rate. Moreover, increase of temperature during cocoa fermentation is undissociable

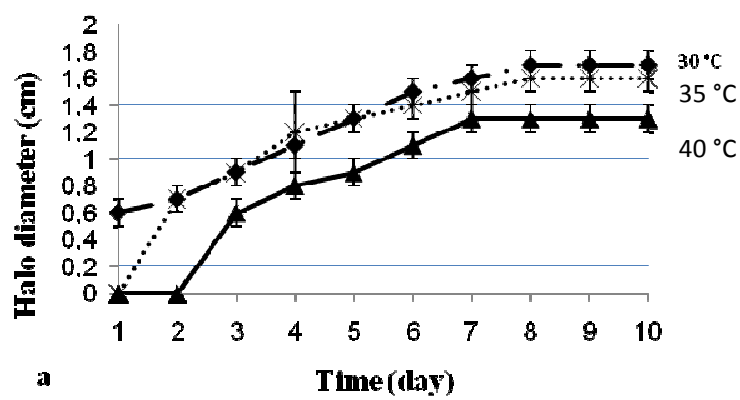

factor of this process. Generally, the temperature of the fermenting cocoa mass reaches $35^{\circ} \mathrm{C}$ in the first 24 hours of fermentation corresponding to ethanol production by yeast strains. After 36 to 72 hours of cocoa fermentation, the bioconversions of ethanol in acetic acid caused increase of temperature to a peak at about $45{ }^{\circ} \mathrm{C}$ value (Schawn, 1998; Fowler, 2009; Samagaci et al., 2014). Therefore, a high AAB activity in cocoa fermenting heap could lead to inhibition of acetic acid production capacity and consequently a decrease of fermented cocoa quality. As both high temperatures and high acid production are important for successful cocoa beans fermentation and obtaining of cocoa quality, further investigations are needed to understand the inability of these thermotholerant strains to produce acetic acid and to improve their acidification capacity under high temperature conditions. Figure $1 \mathrm{~b}$ shows the effect of variation of $\mathrm{pH}$ values on the acetic acid production capacity of strain $121 \mathrm{D}$. This result is same for all tested isolates. The results indicated that acetic acid optimal production was observed at initial pH 5 (with $3.5 \mathrm{~cm}$ as maximum clear halo diameter) probably because optimum $\mathrm{pH}$ for the growth of acetic acid bacteria is range from pH 5 to 6.3 (Holt et al., 1994).

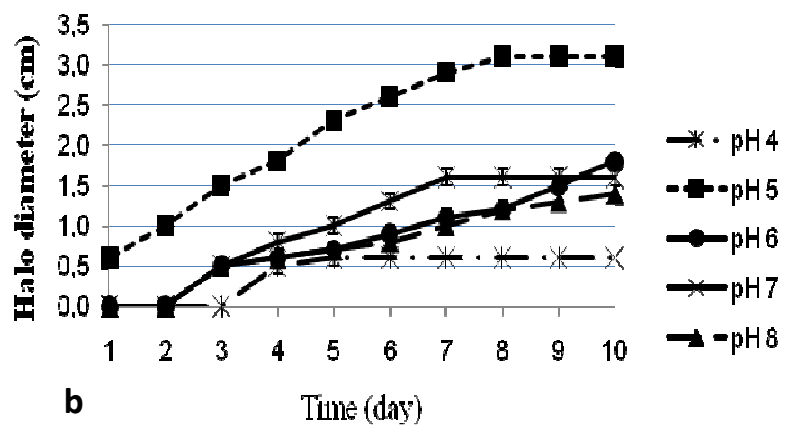

Figure 1: Effect of variation of temperature (a) and pH (b) on acidification capacity of strains $49 \mathrm{D}(\mathrm{a})$ and $121 \mathrm{D}(\mathrm{b})$

The medium HS containing $4 \%$ of ethanol was spot inoculated with tested strain and incubated at different temperatures $\left(30,35,40,45\right.$ and $\left.50^{\circ} \mathrm{C}\right)$. The effect of $\mathrm{pH}$ was evaluated in $\mathrm{HS}$ medium adjusted to different $\mathrm{pH}(4 ; 5 ; 6 ; 7$ and 8$)$. Acidifying capability of strains was assessed by acid forming colony characterized by a clear halo with a diameter related to the amount of acid produced after incubation. Furthermore, the lower activity is observed after 3 days lag time for $\mathrm{pH} 4$ culture medium (Figure 1b). In addition, no acetic acid production was obtained during the 2 first days of incubation at $\mathrm{pH} 6, \mathrm{pH} 7$ and $\mathrm{pH}$ 8. During cocoa fermentation, $\mathrm{pH}$ increased from 3.88-4.2 at start of fermentation to 4.8-5.02 after 3 days and 4.15-8 at the end of the seventh day (Samagaci et al., 2014; Afoakwa et al., 2013 ; Ardhana and Fleet, 2003; Guehi et al., 2010). On the other hand, acetic acid bacteria reach a maximum growth after three days of fermentation when fermenting heap $\mathrm{pH}$ value around 5 (Kouamé et al 2015; Yao et al., 2014). These data clearly explains why Afoakwa et al. (2013) found that acidity level, due probably to acetic acid, was highest at 


\section{Soumahoro et al. J. Appl. Biosci. Effects of culture conditions on acetic acid production by bacteria isolated from Ivoirian fermenting cocoa (Theobroma cacao L.) beans}

3 days of fermentation. In addition, in previous studies, Soumahoro et al. (2015) reported a good growth capacity of these strains at $\mathrm{pH}$ values ranged 3 to 7 . Consequently, variation of the $\mathrm{pH}$ values during a cocoa fermentation essay could not affect acetic acid production capacity of tested strains.

Effect of initial ethanol concentration on acetic acid production: Results for strain $49 \mathrm{D}$ after ten days incubation is shown in Figure 2. Table 1 shows clear halo diameters for all strains after 10 days of incubation. Maximum acid production capacity was obtained with $4 \%$ ethanol as initial concentration for strains $121 \mathrm{D}$ and $139 \mathrm{D}$ and with $8 \%$ for the isolates $A$. Pasteurianus (123 D), A. peroxydans (56 AB) and G. oxydans (49 D) (Table 1). These results are consistent with those reported by Romoreo-Cortes et al. (2012) and Ardhana and fleet (2003) with AAB strains isolates from cocoa beans heap fermenting. These results also are interesting because ethanol is a major metabolite of cocoa pulp fermentation (Roelofsen, 1958) and the maximum rate of ethanol produced by the yeast is around $8 \%$ during this process (Camu et al., 2008; Lefeber et al., 2012; Ho et al., 2014). Moreover, at ethanol initial concentration of $12-15 \%$, a low effect on acetic acid production capacity of strain $56 \mathrm{AB}$ was observed comparatively to the control whose reduction rate was estimated to $45-85 \%$ (Figure 2). These results are same for the all tested strains. So, these isolates could be used in combination with highly ethanol producing yeast isolates to improve the final fermenting cocoa quality.

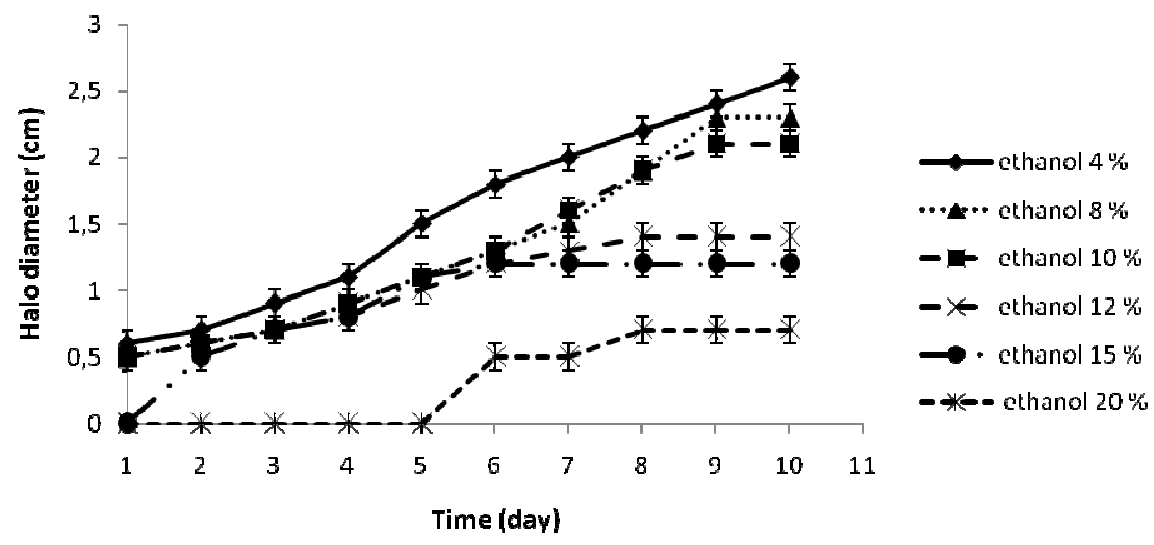

Figure 2: Effect of initial ethanol concentration on acetic acid production

Various concentrations of ethanol $(4,8,10,15$ and 20 $\%)$ were added to the culture medium before the tested strain was inoculated by spot. Acidification capacity was evaluated after incubation by measuring of yellow zone diameter.

Table 1: Effect of initial ethanol concentration on acetic acid production after 10 days incubation

\begin{tabular}{|c|c|c|c|c|c|c|}
\hline & \multicolumn{6}{|c|}{ Halo diameter $(\mathrm{cm})$} \\
\hline & $4 \%$ & $8 \%$ & $10 \%$ & $12 \%$ & $15 \%$ & $20 \%$ \\
\hline $\begin{array}{l}\text { 121D } \\
\text { (A. pasterianus) }\end{array}$ & $2.5 \pm 0.1$ & $2.2 \pm 0.1$ & $1.5 \pm 0.1$ & $1.4 \pm 0.1$ & $0.7 \pm 0.1$ & 0 \\
\hline $\begin{array}{l}\text { 123D } \\
\text { (A. pasterianus) }\end{array}$ & $2.2 \pm 0.1$ & $2.6 \pm 0.1$ & $2.1 \pm 0.1$ & $1.8 \pm 0.1$ & $1.4 \pm 0.1$ & $0 \pm 0.1$ \\
\hline $\begin{array}{l}56 \mathrm{AB} \\
\text { (A. peroxydans) }\end{array}$ & $1.9 \pm 0.1$ & $2.5 \pm 0.1$ & $1.8 \pm 0.1$ & $1.6 \pm 0.1$ & $1.1 \pm 0.1$ & $1.1 \pm 0.1$ \\
\hline $\begin{array}{l}139 D \\
\text { (A. aceti) }\end{array}$ & $2.6 \pm 0.1$ & $2.3 \pm 0.1$ & $2.1 \pm 0.1$ & $1.4 \pm 0.1$ & $1.2 \pm 0.1$ & $0.7 \pm 0.1$ \\
\hline 49D (G. oxydans) & $2.2 \pm 0.1$ & $2.3 \pm 0.1$ & $1.8 \pm 0.1$ & $1.7 \pm 0.1$ & $1.5 \pm 0.1$ & $0 \pm 0$ \\
\hline
\end{tabular}




\section{Soumahoro et al. J. Appl. Biosci. Effects of culture conditions on acetic acid production by bacteria isolated from Ivoirian fermenting cocoa (Theobroma cacao L.) beans}

Effect of acids initial concentration on $A A$ production capacity: The influence of organic acids on the acid production capacity was performed in the HS medium supplemented with $0-1 \%$ of citric, lactic and acetic acids. The results showed that at 0.1 and $0.4 \%$ initial concentration, lactic acid promoted acidification capacity of the tested strain with increase rate ranged from 50 to $100 \%$ comparatively to the control $(0 \%$ of lactic acid). Likewise, at $1 \%$ initial concentration, citric acid promoted acetic acid production in culture medium (figure 3). However, unlike these acids, acetic acid reduced this capacity with decrease rate reached 100 $\%$ after one-day incubation (Figure 3). After this, acetic acid amount gradually increased in culture medium until the end of incubation. These results suggested that acetic acid produced by AAB during cocoa fermentation is probably a temporary inhibition factor of enzymes involved in conversion of ethanol to acetic acid. On the over hand, several authors have reported changes in acids concentration in the pulp during fermentation process with values ranged from 1-3 \% (Galvez et al., 2007; Camu et al., 2008; Lefeber et al., 2011; Papalexandratou et al., 2011), 1-2 \% (Quesnel, 1965) and $0.6-2.9 \%$ (Ho et al., 2014) respectively for citric, acetic and lactic acids. Consequently, this suggested that such conditions might prevent the production of acetic acid by these isolates during cocoa fermentation assay since Soumahoro et al. (2015) found in previous study incapacity of all tested strains to grow at acid initial concentration above $1 \%$. However, it is well known that $A A B$ are involved in acetic acid production during fermentative process under these conditions (Schwan and Wheals, 2004) suggesting an adaptation capacity to the cocoa fermentation stress conditions. Therefore, procedures for selection of microorganisms strains as cultures starter, should take into account these factors. In this context, cocoa fermentation assay is needed to better estimate the acetic acid production capacity of our selected strains.
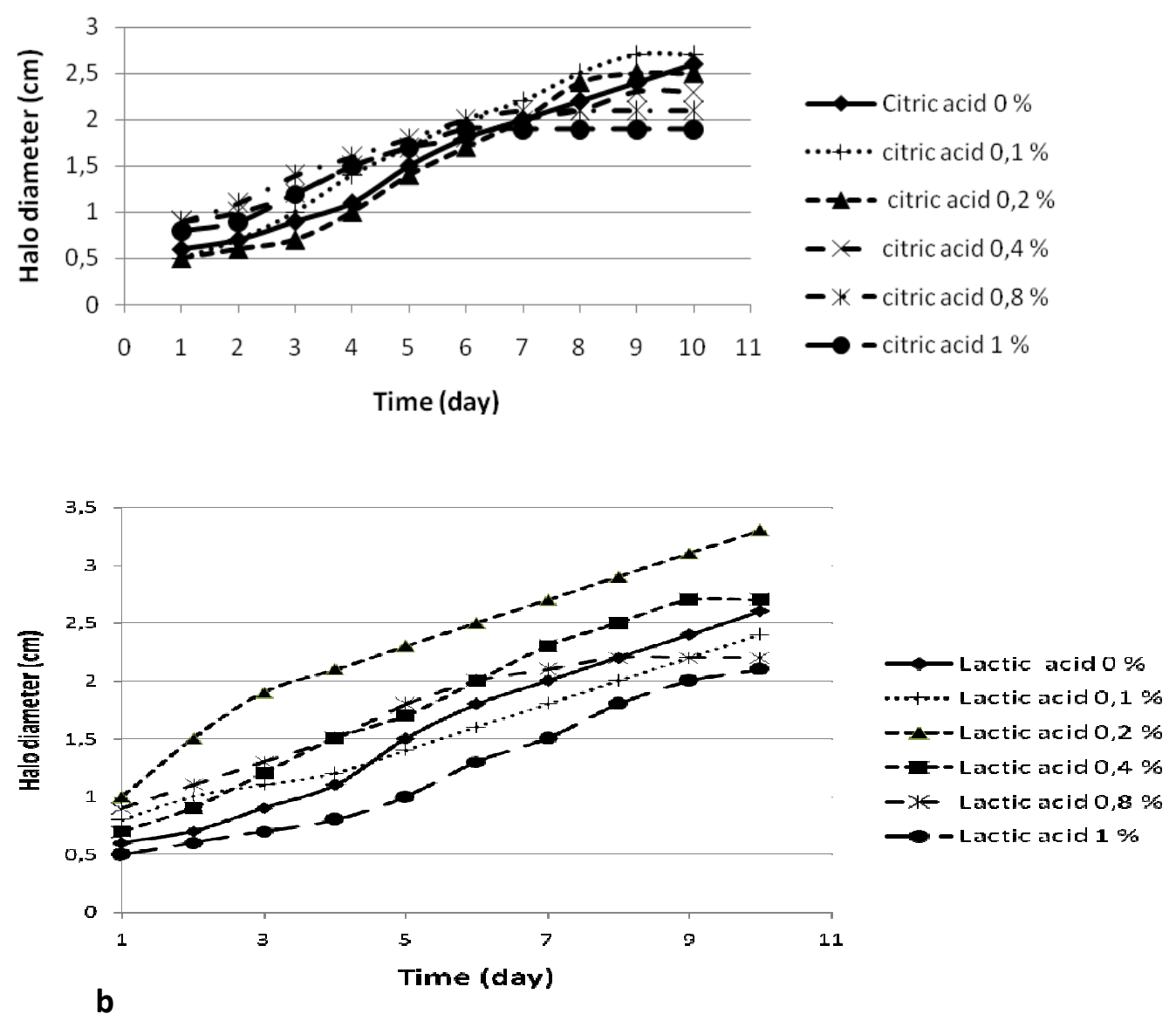


\section{Soumahoro et al. J. Appl. Biosci. Effects of culture conditions on acetic acid production by bacteria isolated from Ivoirian fermenting cocoa (Theobroma cacao L.) beans}

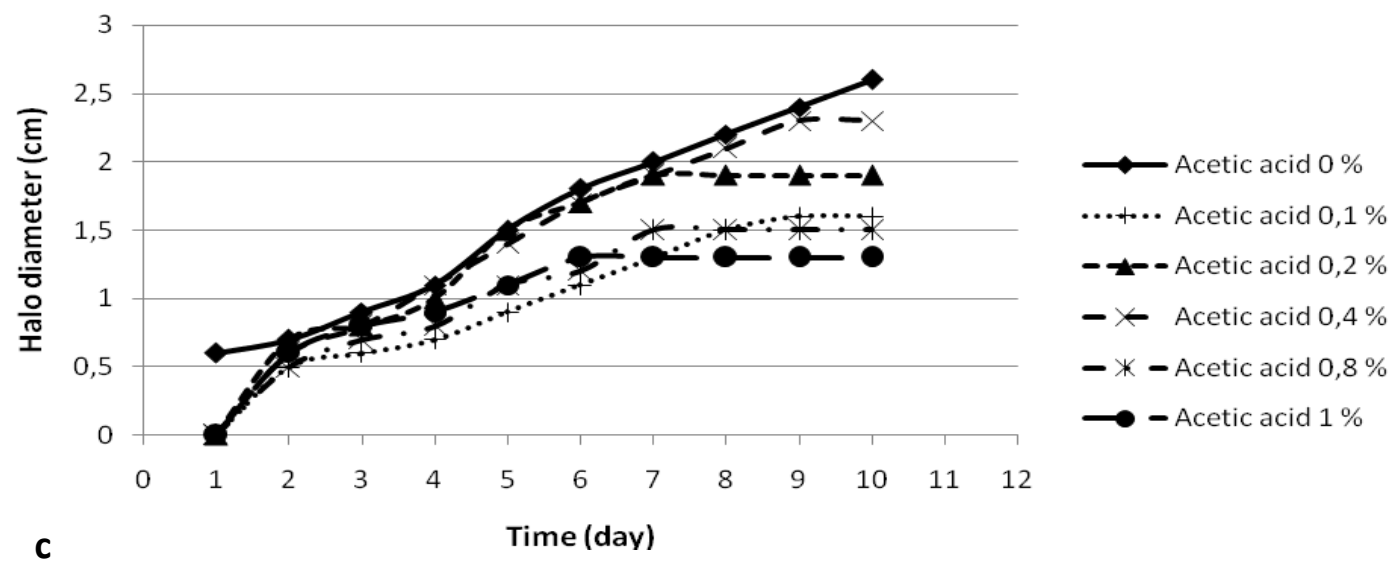

Figure 3: Effect of initial acid concentration on acetic acid production.

(a): citric acid, (b): lactic acid, (c): acetic acid

In conclusion, the tested strains were able to produce acetic acid under different culture conditions. In addition, strains $123 \mathrm{D}, 56 \mathrm{AB}, 139 \mathrm{D}$ and $49 \mathrm{D}$ revealed their maximum acidification capacity under

\section{REFERENCES}

Afoakwa EO, Kongor JE, Takrama JF and Budu AS, 2013. Changes in acidification, sugars and mineral composition of cocoa pulp during fermentation of pulp pre-conditioned cocoa (Theobroma cacao) beans. International Food Research Journal 20(3): 1215-1222.

Andelib AY, Nuran DA, 2009. Isolation of cellulose producing bacteria from wastes of vinegar fermentation. In: Proceedings of the World Congress on Engineering and Computer Science Vol I, San Francisco, USA. pp. 978988.

Ardhana M and Fleet G, 2003. The microbial ecology of cocoa bean fermentations in Indonesia. International Journal of Food Microbiology, 87-99. http://dx.doi:10.1016/S01681605(03)00081-3.

Biehl B, Brunner E, Passern D, Quesnel VC, Adomako D, 1985. Acidification, proteolysis and flavour potential in fermenting cocoa beans. Journal of the Science of Food and Agriculture $36(7)$ : 583-598. http://dx.doi: 10.1002/jsfa.2740360710.

Camu N, Gonzalez A, DE Winter T, Van Schoor A, DE Bruyne K, Vandamme P, Takrama JS, Addo SK, DE Vuyst L, 2008. Influence of turning and these stress conditions. Therefore, these isolates could be use as starter in fermentation essay to improve the fermenting cocoa final quality.

environmental contamination on the dynamics of populations of lactic acid and acetic acid bacteria involved in spontaneous cocoa bean heap fermentation in Ghana. Applied and Environment Microbiology, 74, 86e98. http://dx.doi:10.1128/AEM.01512-07.

Fowler MS, 2009. Cocoa beans: from tree to factory, In: Beckett, S.T. (Ed.), Industrial chocolate manufacture and use, 4th ed. Blackwell Science, Oxford, pp. 10-47.

Galvez-Lagunez S, Loiseau G, Paredes JL, Barel M, Guiraud J-P, 2007. Study on the microflora and biochemistry of cocoa fermentation in the Dominican Republic. International Journal of FoodMicrobiology, 114:124-130. ttp://dx.doi:10.1016/j.ijfoodmicro.2006.10.041.

Guehi ST, Dabone S., Ban-Koffi L, Kra DK, Zahouli GI, 2010. Effect of turning beans and fermentation method on the acidity and physical quality of raw cocoa beans. Advance Journal of Food Science and Technology, 2:163-171.

Hansen CE, Delolmo M, Burri C, 1998. Enzyme activities in cocoa beans during fermentation. Journal of the Science of Food and Agriculture 77:273-281. http://dx.doi:10.1002/(SICl)1097- 


\section{Soumahoro et al. J. Appl. Biosci. Effects of culture conditions on acetic acid production by bacteria}

isolated from Ivoirian fermenting cocoa (Theobroma cacao L.) beans

0010(199806)77:2<273::AIDJSFA40>3.0.CO;2-M

Hashim P, SelamaT J, Muhammad SKS, Ali A, 1998. Effect of mass and turning time on free amino acid, peptide- $\mathrm{N}$, sugar and pyrazine concentration during cocoa fermentation. Journal of the Science of Food and Agriculture,78:543-550. http://dx.doi:10.1002/ (SICI)1097-0010(199812)78:4<535::AIDJSFA151>3.0.CO;2-6

Ho VTT, Zhao J, Fleet G, 2014. Yeasts are essential for cocoa bean fermentation. International Journal of Food Microbiology, 174: 72-87. http://dx.doi,.org/10.1016/.iffoodmicro.2013.12.014.

Holt JG, Krieg NR, Sneath PHA, Staley JT, 1994. Bergey's Manual of Determinative Bacteriology. Williams \& Wilkins, Baltimore, Maryland.

Kersters K, Lisdiyanti P, Komagata K, Swings J, 2006. The family Acetobacteraceae: the genera Acetobacter, Acidomonas, Asaia, Gluconacetobacter, Gluconobacter and Kozakia. In: Dworkin M, Falkow S, Rosenberg E, Schleifer KH, Stackebrandt E, editors. The prokaryotes. 3. New York: Springer; pp. 163200.

Lefeber T, Gobert W, Vrancken G, Camu N, DE Vuyst $L, 2011$. Dynamics and species diversity of communities of lactic acid bacteria and acetic acid bacteria during spontaneous cocoa bean fermentation in vessels. Food Microbiolology, 28: 457-464.

http://dx.doi:10.1016/j.fm.2010.10.010.

Lefeber T, Janssens M, Camu N, DE Vuyst L, 2010. Kinetic analysis of strains of lactic acid bacteria and acetic acid bacteria in cocoa pulp simulation media to compose a starter culture for cocoa bean fermentation. Applied and Environment Microbiology, 76: 7708-7716. http://dx.doi::10.1128/AEM.01206-10.

Lefeber T, Papalexandratou Z, Gobert W, Camu N, DE Vuyst L, 2012. On-farm implementation of starter culture for improved cocoa bean fermentation and its influence on the flavour of chocolate produced thereof. Food Microbiology, 30:379-392. http://dx.doi:10.1016/j.fm.2011.12.021.

Matsushita K, Toyama H, Adachi O, 1994. Respiratory Chains and Bioenergetics of Acetic Acid Bacteria; in Rose and $\mathrm{AH}$, (ed): Advances in
Microbial Physiology. Academic Press, pp 247-301.

Moghadami F, Soudi MR, Sepehr SH, Rezvanianzade MR, 2013. Evaluation of Thermotolerance of Native Strains of Acetic acid Bacteria in Iran. International Research Journal of Applied and Basic Sciences, 4 (9): 2670-2675

Moryadee A and Pathon-Aree W, 2008. Isolation of thermotolerant acetic acid bacteria from fruits for vinegar production. Research Jo urnal of Microbiology, 3: 209-212. http://dx.doi:10.3923/jm.2008.209.212.

Nielsen DS, Hønholt S, Tano-Debrah K, Jespersen L, 2005. Yeast populations associated with Ghanaian cocoa fermentations analysed using denaturing gradient gel electrophoresis (DGGE). Yeast, 22: 271-284. http://dx.doi:10.1002/yea.1207.

Nielsen DS, Teniola OD, Ban-Koffi L, Owusu M, Andersson T, Holzapfel WH, 2007. The microbiology of Ghanaian cocoa fermentations analysed using culture dependent and culture independent methods. International Journal of Food Microbiology, 114: 168-186. http://dx.doi:10.1016/j.ijfoodmicro.2006.09.010

Papalexandratou Z, Vranckena G, DE Bruyne K., Vandamme P, DE Vuyst L, 2011. Spontaneous organic cocoa bean box fermentations in Brazil are characterized by a restricted species diversity of lactic acid bacteria and acetic acid bacteria. Food Microbiolology, $\quad 28$ : $\quad$ 1326-1338. http://dx.doi:10.1016/j.fm.2011.06.003.

Passos FML, Silva DO, Lopez A, Ferreira LF, Guimarães WV, 1984. Characterization and distribution of lactic acid bacteria from traditional cocoa bean fermentations in Bahia. Journal of Food Science., 49:205-208. http://dx.doi:10.1111/j.13652621.1984.tb13708.x.

Quesnel V.C. 1965. Agents inducing the death of the cacao seeds during fermentation. Journal of the Science of Food and Agriculture, 16:441447. http://dx. doi:10.1002/jsfa.2740160804.

Roelofsen PA, 1958. Fermentation, drying and storage of cacao beans. Advances in Food Research, 8: 225-296. http://dx.doi:10.1016/S00652628(08)60021-X.

Romero-Cortes T, Robles-Olvera V, RodriguezJimenes G, Ramírez-Lepe M, 2012. Isolation 


\section{Soumahoro et al. J. Appl. Biosci. Effects of culture conditions on acetic acid production by bacteria isolated from Ivoirian fermenting cocoa (Theobroma cacao L.) beans}

and characterization of acetic acid bacteria in cocoa fermentation. African Journal of Microbiology Research, 6. (2). 339-347. http://dx.doi: 10.5897/AJMR11.986.

Saeki A, Theeragool G, Matsushit A K, Toyama H, Lotong N, Adachi O, 1997. Development of thermotolerant acetic acid bacteria useful for vinegar fermentation at higher temperatures, Bioscience, Biotechnology, Biochemistry, 61, 138-145. http://dx.doi:10.1271/bbb.61.138.

Samagaci L, Ouattara HG, Goualié BG, Niamke SL, 2014. Growth capacity of yeasts potential starter strains under cocoa fermentation stress conditions in Ivory Coast. Emirates Journal of Food and Agriculture, 26 (10): 861-870. http://dx.doi:10.9755/ejfa.v26i10.18114.

Schwan R F, 1998. Cocoa fermentation conducted with a defined microbial cocktail inoculum. Applied and Environment Microbiology, 64: 1477-1483.

Schwan RF and Wheals AE, 2004. The microbiology of cocoa fermentation and its role in chocolate quality. Critical Reviews in Food Science and Nutrition, 44:204-221 http://dx.doi:10.1080/ 10408690490464104

Schwan RF, Rose AH, Board RG, 1995. Microbial fermentation of cocoa beans, with emphasis on enzymatic degradation of the pulp. Journal of Applied Bacteriology-Symposium, Suppl. 79: 96S-107S.

Sharafi SM, Rasooli I, Beheshti-Maal K, 2010. Isolation, characterization and optimization of indigenous acetic acid bacteria and evaluation of their preservation methods. Iranian Journal of Microbiology, 2 (1): 41-48.

Sievers M, Sellmer S, Teuber M, 1992. A. Bactereuropaeus sp. nov., a main component of industrial vinegar fermenters in central Europe. Systematic Applied Microbiology, 15, 386-392. http://dx.doi:10.1016/S07232020(11)80212-2.

Soumahoro S, Ouattara HG, Goualie BG, Koua G, Doue G, Niamké SL, 2015. Occurrence of High Acetic Acid-Producing Bacteria in Ivorian Cocoa Fermentation and Analysis of Their Response to Fermentative Stress. American Journal of Bioscience. Vol. 3, No. 3, 2015, pp. 70-79. http://dx.doi:10.11648/j.ajbio.20150303.12.

Thompson SS, Miller KB, Lopez AS, 2001. "Cocoa and coffee" in Food microbiology: Fundamentals and frontiers, 2nd ed, M. P. Doyle, L. R. Beuchat, and T. J. Montville, Ed. Washington, American Society Microbiology Press, pp. 721-733.

Thompson SS, Miller KB, Lopez A, Camu N, 2013. Cocoa and coffee, In: Doyle, M.P., Buchanan, R.L. (Eds.), Food Microbiology: Fundamentals and Frontiers, 4th ed. ASM Press, Washington, DC, pp. 881-889.

Tayama k, Minakami H, Fujiyama s, Masai H, Misaki A, 1989. Structure of an acidic polysaccharide elaborated by Acetobacter sp. NBI 1005. Agricultural and Biological Chemistry, . 50: 1271-1278.

Yao W, Ouattara HG, Goualié B, Soumahoro S, Niamke S, 2014. Analysis of some functional properties of acetic acid bacteria involved in Ivorian cocoa fermentation. Journal of Applied Biosciences, 75:6282-6290. http://dx.doi.org/ 10.4314/jab.v75i1.13. 